University of Nebraska - Lincoln

DigitalCommons@University of Nebraska - Lincoln

\title{
THERMAL SHRINKAGE TEMPERATURE OF INTRAMUSCULAR COLLAGEN OF BULLS AND STEERS
}

\author{
M. D. Judge \\ Purdue Agricultural Experiment Station \\ E. D. Aberle \\ Purdue Agricultural Experiment Station, elton.aberle@wisc.edu \\ H. R. Cross \\ United States Department of Agriculture \\ B. D. Schanbacher \\ USDA-ARS
}

Follow this and additional works at: https://digitalcommons.unl.edu/usdaarsfacpub

Part of the Agricultural Science Commons

Judge, M. D.; Aberle, E. D.; Cross, H. R.; and Schanbacher, B. D., "THERMAL SHRINKAGE TEMPERATURE OF INTRAMUSCULAR COLLAGEN OF BULLS AND STEERS" (1984). Publications from USDA-ARS / UNL Faculty. 771.

https://digitalcommons.unl.edu/usdaarsfacpub/771

This Article is brought to you for free and open access by the U.S. Department of Agriculture: Agricultural Research Service, Lincoln, Nebraska at DigitalCommons@University of Nebraska - Lincoln. It has been accepted for inclusion in Publications from USDA-ARS / UNL Faculty by an authorized administrator of DigitalCommons@University of Nebraska - Lincoln. 


\title{
THERMAL SHRINKAGE TEMPERATURE OF INTRAMUSCULAR COLLAGEN OF BULLS AND STEERS ${ }^{1,2}$
}

\author{
M. D. Judge ${ }^{3}$, E. D. Aberle ${ }^{3}$, H. R. Cross ${ }^{4,5}$ and B. D. Schanbacher ${ }^{4}$ \\ Purdue Agricultural Experiment Station ${ }^{3}$, \\ West Lafayette, IN 47907 \\ and \\ US Department of Agriculture ${ }^{4}$, \\ Clay Center, NE 68933
}

\begin{abstract}
Summary
The thermal shrinkage temperature $\left(T_{S}\right)$ of bull muscle collagen was higher $(P<.01)$ than that of steers when averaged over three slaughter ages of 12,15 and $18 \mathrm{mo}$. Collagen $T_{S}$ from bull muscles increased from 12 to 15 mo and decreased from 15 to 18 mo of age, whereas that of steer muscles did not change with age (age $x$ sex interaction, $P<.01$ ). No breed effects (7/8 Charolais, 7/8 Simmental, Angus and Hereford) were detected nor were there breed $x$ sex or breed $x$ age interaction effects on collagen $\mathrm{T}_{\mathrm{s}}$. Carcass electrical stimulation did not affect collagen $T_{S}$ in steer muscle, but there was a trend toward reduction of $T_{S}$ in collagen of bull muscle.

(Key Words: Collagen Shrinkage, Bulls, Steers, Age, Breed, Electrical Stimulation.)

\section{Introduction}

Most of the research studies on the tenderness of bull meat have shown it to be slightly less tender and distinctly more variable in tenderness than meat from steers (Seideman et al., 1982). Boccard et al. (1979) reported that collagen solubility of bull muscles was greater than that of steers at 12 mo of age but decreased markedly between 12 and 16 mo of age;
\end{abstract}

\footnotetext{
${ }^{1}$ Journal Paper No. 9745 of the Purdue Agr. Exp. Sta., Dept. of Anim. Sci.

${ }^{2}$ The technical assistance of Anna Maria Bracker and Alison McCartney is gratefully acknowledged.

${ }^{3}$ Dept. of Anim. Sci.

${ }^{4}$ ARS, SE, Roman L. Hruska U.S. Meat Animal Research Center, P.O. Box 166, Clay Center.

${ }^{5}$ Present address: Dept. of Anim. Sci., Texas A\&M Univ., College Station, TX 77843.

Received December 30, 1983.

Accepted March 7, 1984.
}

tenderness of bull meat decreased between 8 and $16 \mathrm{mo}$ of age, partially coinciding with the decrease in collagen solubility. Those studies were conducted on Afrikaner and Friesland cattle and the sex-associated differences in collagen solubility and tenderness were present in both breeds.

Judge and Aberle (1982) observed that the thermal shrinkage temperature $\left(\mathrm{T}_{\mathrm{S}}\right)$ of bovine intramuscular collagen was relatively high in samples from relatively old cattle. Other experiments in our laboratories showed that collagen $T_{S}$ could be lowered (Judge et al., 1981 ) and meat tenderness improved (Salm et al., 1981 ; Crouse et al., 1983) by carcass electrical stimulation of steers. However, the tenderization of bull carcasses by electrical stimulation was ineffective in the research of Crouse et al. (1983) but effective when performed by Riley et al. (1983).

Regardless of whether the cited differences in collagen $T_{S}$ were due to animal age or electrical stimulation, it is likely that the total number and(or) number of heat-stable intermolecular cross-links in the collagen directly influence the heat stability of collagen fibrils. Consequently the observed sex differences in meat tenderness, collagen solubility and response to carcass electrical stimulation may relate to collagen cross-linking and(or) $\mathrm{T}_{\mathbf{S}}$.

The objective of this study was to compare the $T_{S}$ of intramuscular collagen of bulls and steers and to determine the influences, if any, of breed, age and carcass electrical stimulation.

\section{Experimental Procedure}

Forty bulls and 44 steers of four breeds (7/8 Charolais, 7/8 Simmental, Angus and Hereford) were used in this study. At 5 mo of age they were placed on a diet of $78 \%$ corn silage (IFN 
3-08-153), 10\% corn (IFN 4-02-931) and 12\% supplement. Diets varied as animals matured, with the final diet being $42.7 \%$ corn silage, $54.1 \%$ corn and $3.2 \%$ supplement.

The cattle were assigned randomly within each breed and sex to one of three groups to be slaughtered at 12,15 or 18 mo of age. Within 1 $\mathrm{h}$ postmortem, the right side of each carcass was electrically stimulated. The stimulation consisted of 17 impluses at $550 \mathrm{~V}$ (AC), 2 to $2.5 \mathrm{~A}$ and $60 \mathrm{~Hz}$ for a 1.8 -s duration with a 1.8 -s pause between impluses. A single probe was inserted in the muscles between the scapula and the thoracic vertebrae and the carcasses were grounded through the rail.

Immediately after electrical stimulation, longissimus muscle samples were obtained from the second to third lumbar region of both carcass sides. The samples were frozen in liquid $\mathrm{N}_{2}$ after removal of the epimysial connective tissue and stored at $-25 \mathrm{C}$ for as long as $4 \mathrm{wk}$.

The frozen samples were subjected to the connective tissue isolation procedure of $\mathrm{McCl}$ ain (1969) and the collagen $T_{S}$ was determined with a thermal analyzer equipped with a differential scanning calorimeter cell (Judge et al., 1981).

Carcass grade and palatability data were collected and reported by Cross et al. (1984).

The data were subjected to the Harvey (1960) least-squares analysis. The effects of sex, breed, age, electrical stimulation, all possible two-factor interactions and specific three-factor interactions were determined.

\section{Results and Discussion}

Collagen from bull muscles shrunk (i.e., underwent endothermic transition) at higher temperatures than that of steers $(\mathrm{P}<.01$; tables 1 and 2). The mean $T_{S}$ for the steers was similar to the value reported earlier for 16-mo-old steers and heifers, but the mean for bulls was very close to that of aged cows (Judge and Aberle, 1982). Because the cross-linking of collagen is known to occur with advancing age (Goll et al., 1964), it is possible that the higher $\mathrm{T}_{\mathrm{s}}$ of bull muscle collagen was caused by an accelerated rate of collagen maturation in bulls as compared with steers. Research reviewed by Hall (1976) suggests that the synthesis and tensile strength of collagen may be increased by anabolic steroids such as testosterone.

The breeds used in this study did not differ in $T_{S}$ of intramuscular collagen nor was there a breed $x$ sex, breed $x$ age or breed $x \operatorname{sex} x$ age interaction even though both early and late maturing breeds were utilized in the study (tables 1 and 2 ). Assuming that $T_{S}$ value partially reflects collagen solubility, these results do not support the findings of Boccard et al. (1979), which indicated that late maturing Afrikaner bulls and steers had higher muscle collagen solubility than Friesland bulls and steers at 12 to 24 mo of age.

Overall age differences in collagen $T_{S}$ were noted, suggesting that the stability of the collagen was greatest at 15 mo of age $(\mathrm{P}<.10$; tables 1 and 2). However, sex $x$ age interaction effects indicate that only the bull muscle

TABLE 1. LEAST-SQUARES ANALYSIS OF VARIANCE FOR COLLAGEN THERMAL SHRINKAGE TEMPERATURE

\begin{tabular}{|c|c|c|c|}
\hline Source & $\mathrm{df}$ & $\mathrm{F}$ & $\mathrm{P}$ \\
\hline Breed $^{a}(B)$ & 3 & .1 & .936 \\
\hline $\operatorname{Sex}^{b}(S)$ & 1 & 36.9 & .000 \\
\hline $\mathrm{B} \times \mathrm{S}$ & 3 & .8 & .478 \\
\hline $\operatorname{Age}^{c}(A)$ & 2 & 2.9 & .063 \\
\hline $\mathrm{B} \times \mathrm{A}$ & 6 & 1.0 & .368 \\
\hline $\mathrm{S} \times \mathrm{A}$ & 2 & 12.6 & .000 \\
\hline $\mathbf{B} \times \mathbf{S} \times \mathbf{A}$ & 6 & .7 & .623 \\
\hline Electrical stimulation (ES) & 1 & 2.4 & .13 \\
\hline $\mathrm{B} \times \mathrm{ES}$ & 3 & .0 & .994 \\
\hline$S \times E S$ & 1 & 4.3 & .007 \\
\hline$A \times E S$ & 2 & 1.5 & .239 \\
\hline
\end{tabular}

$\mathrm{a}_{7 / 8}$ Charolais, $7 / 8$ Simmental, Angus, Hereford.

${ }^{b}$ Bulls, steers.

$\mathrm{c}_{12}, 15,18 \mathrm{mo}$. 
TABLÉ 2. COLLAGEN THERMAL SHRINKAGE TEMPERATURE (C)

\begin{tabular}{|c|c|c|c|}
\hline Group & No. & Mean & $\mathrm{SE}^{\mathrm{a}}$ \\
\hline \multicolumn{4}{|l|}{ Sex** } \\
\hline Bulls & 40 & 70.2 & .12 \\
\hline Steers & 44 & 69.0 & .11 \\
\hline \multicolumn{4}{|l|}{ Breed } \\
\hline $7 / 8$ Charolais & 17 & 69.7 & .18 \\
\hline 7/8 Simmental & 24 & 69.6 & .15 \\
\hline Angus & 21 & 69.6 & .16 \\
\hline Hereford & 22 & 69.6 & .16 \\
\hline \multicolumn{4}{|c|}{ Electrical stimulation } \\
\hline ES & 84 & 69.5 & .11 \\
\hline Control & 84 & 69.7 & .11 \\
\hline \multicolumn{4}{|l|}{ Age* } \\
\hline $12 \mathrm{mo}$ & 28 & 69.4 & .14 \\
\hline $15 \mathrm{mo}$ & 28 & 69.9 & .14 \\
\hline $18 \mathrm{mo}$ & 28 & 69.5 & .14 \\
\hline \multicolumn{4}{|l|}{ Sex $x$ age** } \\
\hline Bulls - $12 \mathrm{mo}$ & 14 & 69.6 & .20 \\
\hline Bulls - $15 \mathrm{mo}$ & 13 & 71.2 & .21 \\
\hline Bulls - $18 \mathrm{mo}$ & 13 & 69.8 & .21 \\
\hline Steers - 12 mo & 14 & 69.2 & .20 \\
\hline Steers -15 mo & 15 & 68.7 & .19 \\
\hline Steers - $18 \mathrm{mo}$ & 15 & 69.2 & .19 \\
\hline \multicolumn{4}{|l|}{ Sex $\times$ ES** } \\
\hline Bulls - ES & 40 & 69.9 & .17 \\
\hline Bulls - control & 40 & 70.4 & .17 \\
\hline Steers - ES & 44 & 69.1 & .16 \\
\hline Steers - control & 44 & 69.0 & .16 \\
\hline
\end{tabular}

${ }^{\mathrm{a}} \mathrm{Standard}$ error of least-squares mean.

$* \mathrm{P}<.10$.

**P<.01.

collagen underwent an increase followed by a decrease in $T_{S}(P<.01)$. The decrease in collagen $\mathrm{T}_{\mathbf{S}}$ from 15 to $18 \mathrm{mo}$ of age might be interpreted to reflect an accelerated synthesis of new collagen, but no supporting evidence could be found for such synthesis in muscle from 15to 18 -mo-old bulls.

Carcass electrical stimulation did not affect collagen $T_{S}$ in steer muscle and it only slightly reduced $T_{S}$ in that of buils $(\mathrm{P}<.01$; tables 1 and $2)$. These results are in general agreement with previously reported research, which showed that collagen $T_{S}$ is not affected by electrical stimulation of steer carcasses if they come from cattle fed high energy diets (Judge et al., 1981). The tendency for bull muscle collagen to shrink at a slightly lowered temperature after electrical stimulation suggests the need for further research on carcass electrical stimulation and muscle collagen of bulls. Information is needed on the role of androgenic hormones in matura- tion of collagen and the consequences to meat tenderness.

\section{Literature Cited}

Boccard, R. L., R. T. Naude, D. E. Cronje, M. C. Smith, H. J. Venter and E. J. Rossow. 1979. The influence of age, sex and breed of cattle on their muscle characteristics. Meat Sci. 3:261.

Cross, H. R., J. D. Crouse and M. D. MacNeil. 1984. Influence of breed, sex, age and electrical stimulation on carcass and palatability traits of three bovine muscles. J. Anim. Sci. 58:1358.

Crouse, J. D., S. C. Seideman and H. R. Cross. 1983. The effects of carcass electrical stimulation and cooler temperature on the quality and palatability of bull and steer beef. J. Anim. Sci. 56:81.

Goll, D. E., W. G. Hoekstra and R. W. Bray. 1964. Age-associated changes in bovine muscle connective tissue. II. Exposure to increasing temperature. J. Food Sci. 29:615.

Hall, D. A. 1976. The Ageing of Connective Tissue. Academic Press, New York.

Harvey, W. R. 1960. Least-squares analysis of data 
with unequal subclass numbers. USDA, ARS $20: 8$.

Judge, M. D. and E. D. Aberle. 1982. Effects of chronological age and postmortem aging on thermal shrinkage temperature of bovine intramuscular collagen. J. Anim. Sci. 54:68.

Judge, M. D., E. S. Reeves and E. D. Aberle. 1981. Effect of electrical stimulation on thermal shrinkage temperature of bovine muscle collagen. J. Anim. Sci, 52:530.

McClain, P. E. 1969. Isolation of intramuscular connective tissue. Nature 221:181.

Riley, R. R., J. W. Savell, C. E. Murphey, G. C. Smith,
D. M. Stiffler and H. R. Cross. 1983. Effects of electrical stimulation, subcutaneous fat thickness and masculinity traits on palatability of beef from young bull carcasses. J. Anim. Sci. 56:584.

Salm, C. P., E. W. Mills, E. S. Reeves, M. D. Judge and E. D. Aberle. 1981. Effect of electrical stimulation on muscle characteristics of beef cattle fed a high energy diet for varying lengths of time. J. Food Sci. 46:1284.

Seideman, S. C., H. R. Cross, R. R. Oltjen and B. D. Schanbacher. 1982. Utilization of the intact male for red meat production: A review. J. Anim. Sci. $55: 826$. 